\title{
Interactive comment on "Understanding and improving model representation of aerosol optical properties for a Chinese haze event measured during KORUS-AQ” by Pablo E. Saide et al.
}

\section{Anonymous Referee \#1}

Received and published: 4 December 2019

Review of article: "Understanding and improving model representation of aerosol optical properties for a Chinese haze event measured during KORUS-AQ" by Pablo $E$. Saide et al.

\section{General comments}

This work evaluates the deficiencies in the estimation of aerosol optical properties from aerosol mass in the WRF-Chem model. Within the international air quality field study KORUS-AQ, authors found out that aerosol optical depth (AOD) data assimilation works properly but surface particulate concentrations were over-predicted by WRFChem. 
Following these results, the authors explain that these discrepancies can be due to 1) how well the model represents the aerosol properties which drive the optical properties computation (e.g., size distribution, composition, concentrations, etc.); and 2) the accuracy of the optical properties code.

First, authors scrutinize the accuracy of the optical properties by running this code using in-situ observations of size distribution and compositions as inputs. They found that a finer size bin representation and an update of refractive indices and hygroscopicity parameters make computed optical properties closer to the measured ones.

After that the authors tried to evaluate how the model represents the aerosol properties which drive the optical properties computations. With this objective, they run a set of simulations with different aerosol options and taking into account or not the results previously found. This experiment reveals the inability of sectional and modal aerosol configuration in WRF-Chem to properly reproduce the observed size distribution among the underestimation of organic aerosol density and the overprediction of the fractional contribution of inorganic aerosols other than those already taken into account.

Although, in my opinion this is an interesting work, I have found some important issues that deserve a major revision and could, in my opinion, improve the overall quality of this work.

Firstly, I think that a deeply revision of the Results and discussion section should be done in order to include numerical results. In my opinion, in this section authors correctly describes figures qualitatively and make a discussion of the results, but they do not provide a description of the numerical results found. Figures should be described indicating the numerical results found. For instant, in sections 3.1 and 3.2 authors described the results in Figure 9, but they should include the numerical results from observations and the different closure studies. In my opinion, this should be done with all figures and, in particular, through the Results and discussion section for a better

Printer-friendly version

Discussion paper
Interactive

comment 
understanding of the work.

On the other hand, in section 2.1 the model setup is described but the authors do not indicate two important issues. How natural emissions, such as, desert dust or sea salt, or biogenic emissions are being considered by WRF-Chem? This should be mentioned and explained due to the high influence of this emissions on particulate matter.

Moreover, they do not indicate whether $\mathrm{ARI}$ and $\mathrm{ACl}$ were taken into account in the configuration of the simulations. Previous works, such as, Palacios-Peña et al., 2017; 2018 have demonstrated an improvement in the representation of AOD when these interactions were taken into account. This should be clarified and taken into account in the discussion of the results.

Finally, why authors use Level 1.5 of AERONET instead of Level 2.0 whose quality is assured? Authors may find useful to use data from the MAN network ( https://aeronet.gsfc.nasa.gov/new_web/maritime_aerosol_network.html ).

Specific Comments Abstract It would be useful to describe results join to some quantified results.

Introduction I recommend a revision and an improvement of this section. I attach in this review some references that could enhance this section.

âĂć Lines 62-63: "Again, this translation of aerosol mass to optical properties is performed in these models, often showing large inter-model variability (Myhre et al., 2013; Stier et al., 2013)" Similar inter-model variability was found also by Kipling et a.,2016. âÁć Lines 74-76: "Crippa et al. (2019) performed an ensemble of simulations to assess what combination of model inputs and configurations resulted in the best agreement to observations in the southeast US." Palacios-Peña et al. 2019 and Curci et al. 2019 also investigated aerosol optical properties representation over Europe. Methods âĂć 2.1. Regional modelling: Lines 130-135: "... WRF-Chem can also be configured with the Modal Aerosol Dynamics Model for Europe (MADE) model, where aerosol sizes are 
represented by log-normal modes (as opposed to sections as for MOSAIC). We used the configuration coupled to the updated Regional Atmospheric Chemistry Mechanism (RACM, Ahmadov et al., 2014) which contains secondary organic aerosol formation using the volatility basis-set (Ahmadov et al., 2012) and aerosol optical properties calculations (Tuccella et al., 2015). We label these simulations as RACM\#, with \# going from 1-4 depending on changes to parameters described in Table 1." For an easy understanding of the manuscript, I would recommend a rename of the label for the modal distribution. Instead of use RACM\#, I would use MADE\#. This is because the aerosol module is MADE and not RACM which is the gas-phase module. This could lead to a mis-understating in reading. âĂć 2.1. Regional modelling: Lines 137-138: "All retrospective simulations were performed only for the $20 \mathrm{~km}$ resolution domain in this study, as we focus on a pollution event from long range transport." Please remind the date of the episode in this part of the text. âÁć 2.2. Optical properties calculation. Line 150 and somewhere hereinafter. The authors indicate that off-line versions of optical properties calculation from WRF-Chem are needed. What do you mean with off-line versions? Do you mean without $A R I$ and $A C l$ ? This should be clarified. âĂć 2.3. Airborne Observations. Line 175: What is the meaning of NASA DC-8? Please clarify. The authors should be careful with this kind of nomenclature, in particular, taking into account non specialist observational readers.

Results âĂć Lines 432-434: "Another point to note is that models under-predict the relative magnitude of the coarse aerosols (2.5-10 $\mu \mathrm{m}$ range, bin \#4 in the 4-bin configuration). This helps to explain why the biases shown in Figure 5 are more pronounced for PM2.5 than PM10, as the under-prediction in the coarse aerosols is offset by the over-prediction in the fine aerosols." Similar results were found by Balzarini et al. 2015 and Im et al. 2015. âĂć Figure 7: What represents the red line? This should be clarified both in text and in figure caption.

Technical Comments (of purely technical corrections at the very end: typing errors, etc.)

Interactive

comment
Discussion paper
Printer-friendly version

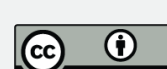


âÁć Through the text: "Angstrom" should be corrected by "Ånsgtröm". âĂć Check for the parenthesis related with acronyms and cites. Some examples are: o Line 107: "geostationary satellites (Geostationary Ocean Color Imager retrievals (Choi et al., 2018; Choi et al., 2016))" should be changed by "geostationary satellites (Geostationary Ocean Color Imager retrievals; Choi et al., 2018; Choi et al., 2016)". o Line 183: "High-Resolution Time-of-Flight Aerosol Mass Spectrometer (HR-ToF-AMS, hereinafter "AMS" for short) (DeCarlo et al., 2006; Nault et al., 2018)." should be changed by "High-Resolution Time-of-Flight Aerosol Mass Spectrometer (HR-ToF-AMS, hereinafter "AMS" for short; DeCarlo et al., 2006; Nault et al., 2018)." o Line 186: "Particle Soot Photometer (SP2) (Lamb et al., 2018)." should be changed by "Particle Soot Photometer (SP2; Lamb et al., 2018)." o Line 192: "Particle Soot Absorption Photometer (at 470, 532, and 660nm wavelength) (Ziemba et al., 2013)." should be changed by "Particle Soot Absorption Photometer (at 470, 532, and 660nm wavelength, Ziemba et al., 2013)." o Line 198: "High Spectral Resolution Lidar (HSRL) (Hair et al., 2008)" should be changed by "High Spectral Resolution Lidar (HSRL; Hair et al., 2008)". o Line 228: "Rubidium originates either from soil (e.g., dust) (Kabata-Pendias and Pendias, 2001)" should be changed by "Rubidium originates either from soil (e.g., dust; Kabata-Pendias and Pendias, 2001)" o Line 297: "KORUS-AQ flights (and thus not detected by AMS) (Heim et al., 2019)," should be changed by "KORUS-AQ flights (and thus not detected by AMS; Heim et al., 2019)," âÁć Line 186: "of New Hampshire usingTeflon filters" add a gap "of New Hampshire using Teflon filters".

Bibliography Balzarini, A., Pirovano, G., Honzak, L., Žabkar, R., Curci, G., Forkel, R., ... \& Grell, G. A. (2015). WRF-Chem model sensitivity to chemical mechanisms choice in reconstructing aerosol optical properties. Atmospheric Environment, 115, 604-619. Curci, G., Alyuz, U., Barò, R., Bianconi, R., Bieser, J., Christensen, J. H., Colette, A., Farrow, A., Francis, X., Jiménez-Guerrero, P., Im, U., Liu, P., Manders, A., Palacios-Peña, L., Prank, M., Pozzoli, L., Sokhi, R., Solazzo, E., Tuccella, P., Unal, A., Vivanco, M. G., Hogrefe, C., and Galmarini, S.: Modelling black carbon absorption of solar radiation: combining external and internal mixing assumptions,

Printer-friendly version

Discussion paper
Interactive

comment 
Atmos. Chem. Phys., 19, 181-204, https://doi.org/10.5194/acp-19-181-2019, 2019. Im, U., Bianconi, R., Solazzo, E., Kioutsioukis, I., Badia, A., Balzarini, A., ... \& Curci, G. (2015). Evaluation of operational on-line-coupled regional air quality models over Europe and North America in the context of AQMEII phase 2. Part I: Ozone. Atmospheric Environment, 115, 404-420. Kipling, Z., Stier, P., Johnson, C. E., Mann, G. W., Bellouin, N., Bauer, S. E., Bergman, T., Chin, M., Diehl, T., Ghan, S. J., Iversen, T., Kirkevåg, A., Kokkola, H., Liu, X., Luo, G., van Noije, T., Pringle, K. J., von Salzen, K., Schulz, M., Seland, Ø., Skeie, R. B., Takemura, T., Tsigaridis, K., and Zhang, $\mathrm{K}$.: What controls the vertical distribution of aerosol? Relationships between process sensitivity in HadGEM3-UKCA and inter-model variation from AeroCom Phase II, Atmos. Chem. Phys., 16, 2221-2241, https://doi.org/10.5194/acp-16-2221-2016, 2016. Palacios-Peña, L., Baró, R., Guerrero-Rascado, J. L., Alados-Arboledas, L., Brunner, D., and Jiménez-Guerrero, P.: Evaluating the representation of aerosol optical properties using an online coupled model over the Iberian Peninsula, Atmos. Chem. Phys., 17, 277-296, https://doi.org/10.5194/acp-17-277-2017, 2017. Palacios-Peña, L., Baró, R., Baklanov, A., Balzarini, A., Brunner, D., Forkel, R., Hirtl, M., Honzak, L., López-Romero, J. M., Montávez, J. P., Pérez, J. L., Pirovano, G., San José, R., Schröder, W., Werhahn, J., Wolke, R., Žabkar, R., and JiménezGuerrero, P.: An assessment of aerosol optical properties from remote-sensing observations and regional chemistry-climate coupled models over Europe, Atmos. Chem. Phys., 18, 5021-5043, https://doi.org/10.5194/acp-18-5021-2018, 2018. Palacios-Peña, L., Jiménez-Guerrero, P., Baró, R., Balzarini, A., Bianconi, R., Curci, G., Landi, T. C., Pirovano, G., Prank, M., Riccio, A., Tuccella, P., and Galmarini, S.: Aerosol optical properties over Europe: an evaluation of the AQMEll Phase 3 simulations against satellite observations, Atmos. Chem. Phys., 19, 2965-2990, https://doi.org/10.5194/acp-19-2965-2019, 2019.

Please also note the supplement to this comment: https://www.atmos-chem-phys-discuss.net/acp-2019-1022/acp-2019-1022-RC1- 
supplement.pdf

Interactive comment on Atmos. Chem. Phys. Discuss., https://doi.org/10.5194/acp-2019-1022, 2019.

Interactive

comment 